\title{
Effectiveness of Physical Therapy Management of Axillary Web Syndrome following Sentinel Lymph Node Biopsy in Breast Cancer Patients: Case Study
}

\author{
Young-Hun Shim¹, Yun-Won Chae', Ji-Won Park ${ }^{3}$ \\ 'Department of Physical Therapy, Rehabilitation Medicine, Samsung Medical Center, Seoul; ${ }^{2}$ Department of Physical Therapy, Gwangju Health \\ University, Gwangju; ${ }^{3}$ Department of Physical Therapy, College of Medical Science, Catholic University of Daegu, Daegu, Korea
}

Purpose: The aim of this pilot study was to determine the effect of soft tissue technique (STT) in Axillary Web Syndrome (AWS) following sentinel Lymph Node Biopsy in breast cancer patients by examining the upper extremity function, range of motion, and pain.

Methods: Nineteen patients with breast cancer-related AWS were evaluated. STT was performed on the symptom area for treatment of AWS symptoms. We evaluated AWS symptoms and pain intensity using a visual analogue scale (VAS), and functional disability using the Korean version of the Disabilities of Arm, Shoulder, and Hand (DASH) questionnaire, glenohumeral joint (GHJ) flexion and abduction range of motion (ROM) with or without elbow extension.

Results: Visual analyses of the data suggest a modest effect of ST in improving GHJ flexion, abduction ROM with or without elbow extension, DASH for upper extremity function, and Pain. The statistically significant improvement in baseline observed for pain, DASH, and ROM data made it impossible to assess the effects of ST on those outcomes. There were no adverse events.

Conclusions: ST may be an effective and safe treatment option for AWS patients recovering from breast cancer treatment; however, further research is needed.

Keywords: Axillary web syndrome, Breast cancer, Sentinel lymph node biopsy, Soft tissue technique

\section{서 론}

유방암은 동양의 여성에서 가장 빈번하게 발생하며 여성암의 발병 률과 사망률에 있어서 중요한 지표가 되는 암이다.1-3 전 세계적으로 매년 100만명이 넘는 여성에서 유방암이 발병하고 있으며 한국의 경 우, 통계청에 따르면 유방암의 유병률은 $15.1 \%$ 에 해당하며 이 수치는 암 중에 두 번째로 높은 발병률이다. ${ }^{4}$ 더군다나 유방암의 경우 5 년 생 존율이 $89.5 \%$ 에 해당할 정도로 높다. 수술이 유방암에 대한 가장 기 본적이고 중요한 치료법임에도 불구하고 이러한 보존적 수술을 한 경우에 상지부종, 어깨관절의 움직임 제한, 통증, 감각이상과 운동기 능이상 등 임상적 문제가 많이 발생한다.5-9 특히 유방암 수술 후 이러 한 상지의 통증과 움직임 제한에 있어서 영향을 주는 것 중에 하나가 axillary web syndrome (겨드랑이막증후군)이다.

겨드랑이막증후군은 "cording"으로 불렸으며 유방암 수술 후 발생

Received Mar 22, 2016 Revised Apr 18, 2016

Accepted Apr 18, 2016

Corresponding author Ji-Won Park

E-mail mylovept@hanmail.net
되는 초기 합병증 중에 하나로 움직임 제한, 통증, 상지기능 손상과 같은 수술 후유증을 일으키는 주요한 요소로 작용한다. 검진상에서 겨드랑이막증후군 환자는 전형적으로 겨드랑이에서 손목까지 연결 된 통증이 동반되어 있는 만져지는 표층부 띠구조물(superficial taut band)이 있으며 동시에 어깨 외전 움직임에 특히 제한이 온다(Figure 1). 보통 수술 후 2-3주째 발생되어 수개월내에 자연 치유되는 질환이 다. 이는 유방암의 진단 및 치료의 과정에서 시행되는 겨드랑이 림프 절 절제술(axillary lymph node dissection, ALND)이나 전초림프절 조 직검사(sentinel lymph node biopsy, SLNB) 뒤에 6-72\%까지 발생한다고 보고된 바 있다.10-13

이렇듯 겨드랑이막증후군은 유방암 환자에게 있어서 관절제한, 운동기능 제한, 통증 등 여러 문제들을 동반하게 하고 수술 후 일상 생활의 문제와 더불어, 앞으로 진행하게 될 방사선 치료에 필요한 어 깨의 관절가동범위에 제한이 오게 되어 방사선 치료의 치료 진행에 


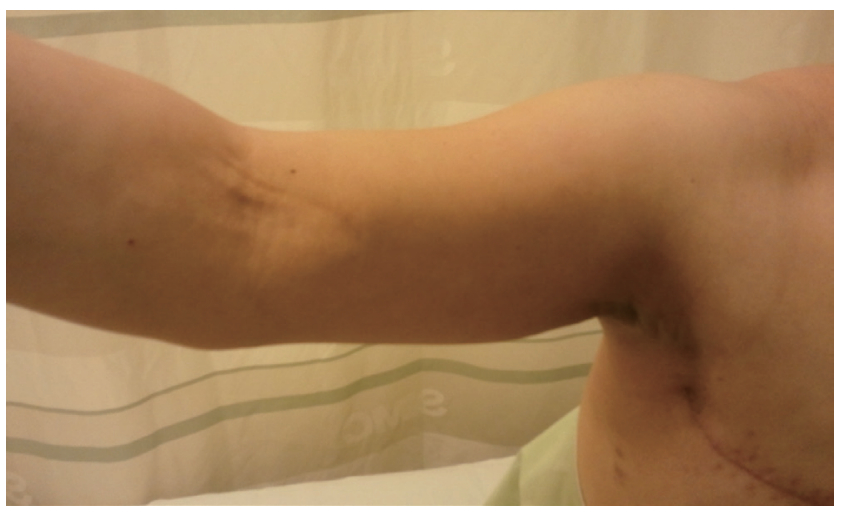

Figure 1. Axillary web syndrome (superficial taut band).

영향을 줄 수 있다.14.15 하지만 치료에 있어서 아직 추천할 만한 가이 드라인이 없는 상태이다. 아직까지 구체적이고 명확한 발생학적 근거 가 없는 겨드랑이막증후군은 자연치유가 되도록 비적극적인 보존적 치료를 위주로 하여 간단한 스트레칭과 어깨 관절 운동이 도움이 되 는 것으로 보고되고 있다.13,16 하지만 정립되어 있는 치료 프로토콜의 부재는 무분별한 치료법의 적용과 부작용을 만들어 낼 수 있다. 최근 겨드랑이막증후군 치료 프로토콜을 제안하는 논문에서 연부조직술 기(soft tissue technique, STT)를 치료에 적용한 사례 보고(case report) 가 나왔으며 겨드랑이막증후군 증상 호전에 의미 있는 변화를 단기 간에 가져온 것으로 보고하였다. ${ }^{17}$ 본 연구는 유방암 환자의 겨드랑 이 수술 이후 겨드랑이막증후군 증상 환자에 대한 적극적인 치료로 STT를 통한 중재 전후 치료 효과의 차이를 확인하여 치료 효과를 규 명함으로써 아직 정립되지 않은 겨드랑이막증후군 환자를 위한 치 료프로그램 개발의 밑거름이 되고자 한다.

\section{연구방법}

\section{1. 연구 대상}

$\bigcirc \bigcirc$ 병원에서 전초림프절 조직검사 수술을 받은 유방암 환자 중 수술 후에 겨드랑이막증후군으로 진단받은 환자로서 특별한 근골격 계, 신경계, 순환계에 이상이 없었으며 가족력이나 과거력이 없는 환 자를 대상으로 하였다. 모든 대상자는 실험에 참가하기 전 실험의 내 용과 절차에 대해 충분히 설명을 들었으며 실험동의서에 서명하였으 며, 자발적으로 실험에 동참하였다.

\section{2. 실험 방법}

1) 실험 설계

(1) 치료군 중재

치료군은 겨드랑이막증후군으로 진단받은 전초림프절 조직검사 만 수술한 유방암 환자들로서 겨드랑이막증후군에 대하여 연부조

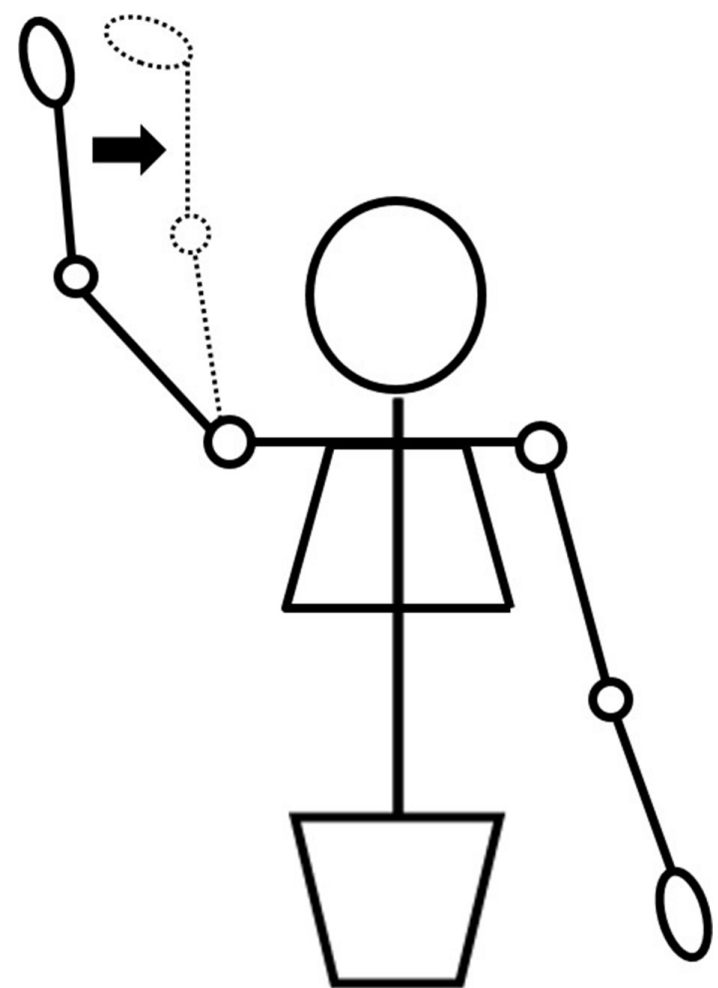

Figure 2. Soft tissue technique position.

직술기를 치료로 적용하고 나서 환자의 상태변화를 확인했다. 치료 프로토콜은 Fourie 등 ${ }^{17}$ 의 겨드랑이막증후군 환자를 대상으로 띠구 조물 부위에 적용한 연부조직술기를 현재 임상상황에 맞게 수정하 여 적용하였다. 연부조직술기 적용 시 어깨 벌림 $100^{\circ}+$ 팔꿈치 굽힘 $90^{\circ}+$ 아래팔의 뒤침과 함께 손목의 완전 폄(shoulder $100^{\circ}$ abduction + elbow $90^{\circ}$ flexion + full wrist extension with forearm full supination + finger extension) 상태에서 팔꿈치를 펴면서 어깨 벌림(elbow extension + shoulder abduction)을 더 실시한다(Figure 2). 환자의 띠구조물이 당 겨지는 느낌을 받는 그 관절 위치에서 연부조직술기를 적용하였다. 연부조직술기 강도는 띠구조물이 스트레칭 되는 정도에 따라 달리 적용하였다(Appendix 1). 초기에는 1 step으로 3회 실시 후 2 step을 적 용하였다. 2 step을 지속적으로 적용하면서 팔꿈치를 완전히 편 상태 로 어깨 벌림 $120^{\circ}$ 를 할 수 있게 되면 3 step을 적용하였다. 일주일에 2 회 외래로 방문하여 20 분동안 치료를 실시하였다. 치료의 시작과 함 께 치료의 종료는 팔꿈치를 펴서 어깨의 완전한 관절가동범위 회복 시까지 지속하는 것으로 하였다. 그래서 치료 종료시점까지의 걸리는 시간 또한 중요한 결과값으로 기존의 연구들의 치료 기간과 비교분 석 하였다. 단, 띠구조물이 남아 있는 경우일지라도 연부조직의 신장 성(elasticity)이 회복되어 완전한 어깨의 관절 가동범위가 측정된 것이 므로 치료를 종료하였다. 또한 전반적인 팔과 어깨와 관련된 기능을 평가하기 위해 어깨 관절가동범위를 측정함과 동시에 Disabilities of 
the Arm, Shoulder and Hands (DASH) 질문지를 사용하였다. 띠구조물 이 보이는 영역과 그 부위에서의 통증의 정도를 평가하기 위해 Visual Analog Scale(VAS)를 측정하였다.

\section{2) 측정도구}

(1) 어깨 관절 가동 범위(range of motion)

겨드랑이막증후군 환자는 만져지는 띠구조물로 인해 팔꿈치를 펴 면서 팔을 들어올리는 동작에서 전형적인 제한을 보인다.5,10,12 그래서 어깨의 가동범위 측정 시 팔꿈치를 편 상태와 펴지 않은 상태로 측정 자세를 구분했다. 팔꿈치를 $90^{\circ}$ 굽힘 상태에서 어깨 관절 가동범위를 측정한 것과 팔꿈치를 완전히 편 상태로 측정하여 팔의 실제적인 기 능적 상태를 좀 더 정확하게 나타내고자 하였고 그렇게 함으로써 겨 드랑이막증후군 증상 호전에 직접적인 연관성을 좀 더 표현하고자 하였다. 결국 팔꿈치는 완전히 펴진 상태에서 편안하게 팔을 들어 귀 까지 닿는 어깨의 완전 가동범위가 나와야 한다.

\section{(2) 상지 기능(upper limb dysfunction)}

상지의 기능적 상태와 연관된 증상 및 징후들을 평가함으로써 상 지의 전반적인 기능이상을 확인하기 위해 널리 사용되고 있는 DASH - 한국버전(K-DASH)을 사용하였다. ${ }^{18} \mathrm{DASH}$ 질문지는 30 문항으로 되어 있으며 각각 5 지선다형으로 되어 있다. 18,19 일상생활에서의 상지 의 기능적 수행을 위한 설문이 21 문항이고(DASH-ADL), 증상(symptom)과 관련된 질문이 5가지이며(DASH-symptom), 심리사회적 (psychsocial) 영향에 대한 3 가지 문항으로 구성되어 있다. DASH 총 점 수는 전반적인 상지의 기능 이상을 평가하기에 충분한 결과를 보여 준다.

\section{(3) 통증(Pain)}

오목위팔관절의 관절가동범위 및 상지의 전반적인 기능을 평가함 과 동시에 통증에 대한 평가를 사용하였다. 따구조물이 보이는 영역 과 함께 그 부위에서의 느껴지는 통증의 정도를 Visual Analog Scale (VAS)를 측정하였다.

\section{3) 자료분석}

본 연구에서 수집된 자료의 통계 분석을 위하여 SPSS version 20.0 프로그램을 사용하여 통계처리를 하였다. 대상자의 일반적 특성을 평균과 표준편차로 분석하였고, 정규성 검정을 위하여 샤리포-윌크 (shapiro-Wilk) 검정 방법을 실시하였다. 치료군의 상지 기능 회복 및 통증에 대한 중재 전후 치료 효과를 비교하기 위하여 대응표본 t-검 정(paired T-test)를 사용하였다. 통계학적 유의수준을 검정하기 위하 여 $\alpha=0.05$ 로 하여 통계 분석을 하였다.

\section{결 과}

\section{1) 연구대상자의 일반적 특성}

본 연구에 참여한 대상자는 총 19 명으로 연부조직술기 치료를 받 았다. 유방암 환자의 특성상 연구 대상자의 성별을 모두 여성으로 동 일하였다. 평균 연령은 50.1세였고 치료가 종료되는 시점은 치료를 시 작한지 평균 25.84 일이었다. 모든 연구 대상자들의 겨드랑이 수술은 전초림프점 조직검사 수술만 하였으며 유방절제술(mastectomy)의 경 우 전절제 수술(total mastectomy)을 한 경우는 10명이었고 9명은 부분 절제술(partial mastectomy)을 받은 환자였다. 겨드랑이막증후군 증상 이 보인 팔은 수술한 부위와 동일하며 오른팔이 11 명, 왼팔이 8 명이었 고 연구대상자 중 18 명이 오른팔 우세손이었고 1 명만 왼손 우세손이 었다. 겨드랑이막증후군 환자의 발병시기는 수술을 하고 나서 평균 적으로 124.74 일로 집계되었다. 하지만 발병시기는 수술한 이후 일주 일 이내부터 증상이 나타난 경우에서부터 수술 한 지 2 년만에 겨드 랑이막증후군이 발병한 경우도 있을 정도로 다양하였다. 증상이 호 발된 부위는 위팔 내측과 팔꿈치 부위가 11 명으로 가장 많았으며 그 다음으로 팔꿈치 영역만 보이는 경우는 3명이었다. 암병기는 2기가 12 명, 3 기가 3 명 그리고 1 기와 0 기가 각각2명씩 확인되었다(Table 1).

\section{2) 통증}

연부조직술기를 적용하여 겨드랑이막증후군을 치료한 이후 통증 변화에 대한 평가에서 중재 전후 통증의 차이에 유의한 차이가 있었

Table 1. General characteristics

\begin{tabular}{llcr}
\hline Characteristics & & Experimental group $(\mathrm{n}=19)$ & $\%$ \\
\hline Gender & Female & 19 & \\
Age (year) & & $50.1 \pm 8.84^{+}$ & \\
AWS side & Right & 11 & 58 \\
& Left & 8 & 42 \\
Breast surgery & Partial mastectomy & 9 & 47 \\
& Total mastectomy & 10 & 53 \\
AWS area & Upper arm + elbow & 11 & 58 \\
& Upper arm & 1 & 5 \\
& Elbow & 3 & 16 \\
& Lower arm & 2 & 11 \\
Onset time (day) & All & 2 & 11 \\
VAS & & $124.74 \pm 164.21$ & \\
Tx duration (day) & & $5.87 \pm 1.68$ & \\
Cancer stage & 0 & $25.84 \pm 9.86$ & \\
& 1 & 1 & 5 \\
& 2 & 3 & 16 \\
& 3 & 12 & 63 \\
\hline
\end{tabular}

${ }^{+}$Mean \pm SD. 
Table 2. Comparison of AWS symptom between the pre and post-test

\begin{tabular}{lccccccc}
\hline & VAS & SFwEF & SFwEE & SAbwEF & SAbwEE & DASH & DASH work module \\
\hline Pre & $5.87 \pm 1.68$ & $145 \pm 20.21$ & $127.37 \pm 23.29$ & $132.11 \pm 28.74$ & $108.68 \pm 27.83$ & $36.93 \pm 15.39$ & $59.19 \pm 83.65$ \\
Post & $1.18 \pm 1.16$ & $177.63 \pm 3.48$ & $176.58 \pm 5.54$ & $179.47 \pm 2.29$ & $178.42 \pm 4.73$ & $10.89 \pm 5.29$ & $11.76 \pm 6.95$ \\
$\mathrm{t}$ & $12.83^{*}$ & $7.39^{*}$ & $9.92^{*}$ & $7.37^{*}$ & $11.62^{*}$ & $9.69^{*}$ & $2.41^{+}$ \\
\hline
\end{tabular}

Mean \pm SD.

VAS: visual analog scale, SFwEF: shoulder flexion with elbow flexion, SFwEE: shoulder flexion with elbow extension, SAbwEF: shoulder abduction with elbow flexion, SAbwEE: shoulder abduction with elbow extension, DASH: Disabilities of the Arm, Shoulder and Hands.

${ }^{*} p<0.01,{ }^{+} p<0.05$.

다 ( $\mathrm{p}<0.05)$. 치료 전 겨드랑이막증후군과 관련된 통증은 VAS 5.87에 서 치료 후 VAS 1.18로 떨어져 통증 경감이 있었다(Table 2).

\section{3) 어깨 관절가동 범위}

겨드랑이막증후군 환자의 연부조직술기 적용을 통한 치료 전후의 어깨 관절가동범위 변화는 굽힘, 벌림 모두 유의한 차이가 있었다 $(\mathrm{p}<0.05)$. 통계 분석 결과 팔꿈치를 구부린 상태의 오목위팔관절 굽 힘 $(\mathrm{t}=7.39, \mathrm{p}<0.01)$, 벌림 $(\mathrm{t}=7.37, \mathrm{p}<0.01)$ 관절가동범위 모두 통계적으 로 유의한 차이를 보였다. 팔꿈치는 편 상태의 오목위팔관절 굽힘 $(\mathrm{t}=9.92, \mathrm{p}<0.01)$, 벌림 $(\mathrm{t}=11.62, \mathrm{p}<0.01)$ 관절가동범위 모두 통계적으 로 유의한차이를 보였다(Table 2).

\section{4) 상지 기능}

겨드랑이막증후군 환자에게 연부조직술기를 적용하여 치료 전후 의 상지 기능 평가를 위해 DASH -한국버전(K-DASH)을 사용하였다 (Table 2). 치료 전후 DASH 점수의 평균은 36,93 점에서 10.89 로 낮아져 유의한 차이를 보였다 $(\mathrm{p}<0.05)$. DASH에서 추가 질문사항으로 상지 기능과 연관된 직업과 일에 대한 항목의 점수 또한 59.19에서 11.76점 으로 낮아져 유의한 차이를 보였으나 $(\mathrm{p}<0.05)$ 스포츠/예술과 관련된 문항은 실제 환자와 관련성이 없는 질문이어서 환자들이 거의 답안 작성을 하지 않아 통계분석에서 빠지게 되었다.

\section{고 찰}

겨드랑이막증후군은 겨드랑이 수술을 한 유방암 환자에게서 보 통 수술 이후 초기에 나타나는 수술 후 후유증 중에 하나이다. 어깨 관절 운동 범위 제한과 함께 위팔 안쪽과 팔꿈치에 일반적으로 발생 하는 띠구조물로 인해 팔꿈치를 펴지 못하며 팔을 사용할 때 통증을 동반하게 된다. 겨드랑이막증후군으로 인해 환자는 단기적으로는 팔 을 펴서 들지 못하고 정상적인 일상생활을 못하는 상황이 되지만 더 욱 문제가 되는 것을 방사선 치료 시 필요한 어깨관절가동범위에 제 한을 만들어 전반적인 암치료 스케줄에 영향을 줄 수 있다는 것이 다.1415 또한 통증이 동반된 팔의 사용으로 오랫동안 정상가동범위에
서 움직이지 못한 어깨관절은 이차성 유착성 관절낭염(secondary adhesive capsulitis)과 같은 심각한 관절의 구축을 만들어 장기간의 치료 가 필요한 상황으로 진행되게 된다. ${ }^{20}$ 겨드랑이막증후군은 이렇게 임 상적으로 연관된 문제들이 많음에도 불구하고 아직 정량화 되어 있 는 치료 프로토콜이 없으며 치료에 있어서 아직 추천할 만한 가이드 라인이 없는 상태이다. 아직까지 구체적이고 명확한 발생학적 근거가 없는 겨드랑이막증후군은 자연치유가 되도록 비적극적인 보존적 치 료를 위주로 간단한 스트레칭과 어깨 관절 운동이 도움이 되는 것으 로 보고되고 있다.13.16

본 연구는 총 19 명의 겨드랑이 전초림프점 조직검사 수술을 한 유 방암 환자 중에 수술 후 겨드랑이막증후군 진단을 받은 환자를 대상 으로 연부조직술기를 치료 중재로 적용하여 겨드랑이막증후군으로 인한 상지기능 저하, 관절운동범위 제한, 통증 등에 있어서 전후 치료 효과에 대하여 알아보았다. 겨드랑이막증후군 환자를 위한 정량적 치료 프로토콜과 제시된 치료법의 적절성을 확인하기 위해 환자에게 실제로 연부조직술기 치료 적용을 한 pilot study이다. 정립되어 있는 치료 프로토콜의 부재로 인해 무분별한 치료법의 적용과 부작용을 최소화 하기 위함이며 이를 통해 환자에게 더욱 적절한 치료법이 만 들어지는 밑거름이 되고자 하였다.

겨드랑이막증후군의 원인을 조직학적으로 규명되지는 않았으나 그 원인에 대한 여러 가지 연관된 주장을 보면 손상 및 당김에 의한 림프정맥계의 파괴와 정체, 손상된 조직에서 유리되는 조직인자(tissue factor)로 인한 과응고화 등으로 보았으며, 그 증거로 띠구조물의 병리학적 소견에서 표층 림프관과 정맥의 확장과 혈전을 관찰할 수 있었다고 하였다. ${ }^{12}$ 또한 과산화수소(hydrogen peroxide)를 이용하여 림프조영술(Lymphangiography)을 적용한 해부학적 연구에서 상지의 림프관들이 동 - 정맥과는 달리 겨드랑이의 표층으로 배출되는 것을 확인할 수 있었다고 하였다. ${ }^{21}$ 이는 겨드랑이 수술로 인해 겨드랑이 표층의 림프계통이 쉽게 손상 받을 수 있음을 설명한다. 본 연구 대 상자들에서도 띠구조물은 모두 표층부에서 나타났으며 이러한 피 부-근막 부위에서의 증상 발현이 연부조직술기를 적용하게 된 배경 이 되었다. 또한 실제 이러한 연부조직술기가 겨드랑이막증후군 증 상 호전에 효과가 있었다는 case report가 보고되었다.17 
겨드랑이막증후군이 겨드랑이 림프절 절제술을 받은 환자의 $72 \%$ 에서, 전초림프점 조직검사를 받은 환자의 $20 \%$ 에서 발생한 것으로 미 루어 보아 유방암 수술과 연관된 겨드랑이 수술의 범위가 넓고 침습 적일수록 겨드랑이막증후군이 발생될 확률이 높고, 겨드랑이막증후 군의 발생과 악성세포의 겨드랑이 전이 여부와는 관계가 없다고 하 였다. 19명에 대한 겨드랑이막증후군으로 인한 겨드랑이 림프절 전이 는 없었다. 본 연구에서도 전초림프점 조직검사 수술을 한 환자들만 을 대상으로 하였으며 겨드랑이 림프절 절제술을 받은 경우 림프부 종의 위험성이 전초림프점 조직검사를 시행한 환자에 비해 더 높기 때문에 대상 환자군을 한정지었다.22,23

또 다른 겨드랑이막증후군 원인 인자로는 통증으로 인한 관절의 운동제한에 대한 초기 운동치료에 대한 잘못된 이해와 섬세하지 않 은 치료적 접근이 문제가 될 수 있다.24,25 이로 인해 새로운 육아조직 이 생기거나 유착성 조직으로 발전하게 되는 결과를 초래하고, ${ }^{25}$ 과 자극으로 인해 진행성 염증성 반응이 더해지면서 과육 섬유화(overproduction of fibrosis)가 진행될 위험에 놓이게 된다. ${ }^{26,27}$ 본 연구 대상 자 19 명 중 11 명에서 수술 후 2 개월 이내에 겨드랑이막증후군이 발생 한 경우로 11 명의 팔꿈치를 굽힌 상태에서 오목위팔관절의 관절가동 범위가 평균 $137.73^{\circ}$ 로 나머지 8 명의 평균 $155^{\circ}$ 보다 낮게 나타난 것으 로 보아수술 후 초기에 발생하는 관절의 운동제한에 대한 잘못된 관 리가 문제가 된 것으로 사료되며 초기에 이러한 통증과 연관된 잘못 된 자가 운동 및 관리에 대한 섬세하고 조심스러운 접근이 필요할 것 으로 생각된다.

겨드랑이막증후군 환자에 대한 연부조직술기 접근은 오목위팔관 절의 관절가동범위를 회복하는 데 있어서 유의한 치료 효과가 있었 다. 특히, 팔꿈치를 편 상태에서의 오목위팔관절 굽힘과 벌림에서 유 의한 치료효과가 있었다. Koehler 등28은 12주 동안 겨드랑이 수술을 한 유방암 환자에게서 겨드랑이막증후군 증상군과 비겨드랑이막증 후군 군에서의 관절가동범위 회복 패턴이 어떠한지 알아보았다. 관 절가동범위는 오목위팔관절의 벌림을 측정하였고 비겨드랑이막증 후군 군과 비교하여 겨드랑이막증후군 증상군의 회복이 수술 후 12 주 정도의 시간이 지나서야 두 군의 관절가동범위가 거의 비슷해진 결과를 얻었다. 일반적으로 겨드랑이막증후군 증상의 자연치유 시간 과 같은 결과를 보여주었다. 하지만 본 연구에서는 겨드랑이막증후 군 환자들에게 좀 더 적극적인 접근으로 연부조직술기를 치료로 적 용하였고 관절가동범위 회복에 걸리는 평균 기간이 25.84 일이었다. 선행연구 ${ }^{10-13,28}$ 들의 겨드랑이막증후군 증상으로 인해 발생한 관절가 동범위 제한이 회복되는데 걸리는 시간에 비해 짧았으며 측정된 관 절가동범위 회복 또한 완전한 가동범위로 회복되어 선행 연구들에 서 보여준 완전 가동범위 회복이 아닌 것과 비교하면 더 나은 결과를 보였다. 이는 적극적인 연부조직술기가 겨드랑이막증후군 환자의 관
절운동 회복에 걸리는 시간을 단축시키고 더 많은 회복을 가능하게 한다는 것을 보여준 임상적 결과이며 전초림프점 조직검사 수술 이 후 발생한 겨드랑이막증후군 치료를 위한 안전하고 좀 더 빠른 치료 법으로 연부조직술기 적용의 높은 가능성을 보여주는 결과이다. 더 욱이 본 연구에서 측정한 관절가동범위 평가에서 팔꿈치를 펴고 측 정한 결과는 좀 더 겨드랑이막증후군에 실제적인 상지 기능을 대변 하는 상지의 관절가동범위 측정이라고 할 수 있으며 겨드랑이막증후 군의 증상의 호전을 단번에 보여줄 수 있는 측정값이라고 생각된다. 본 연구에서는 특히, 팔꿈치를 편 상태에서의 오목위팔관절 굽힘과 벌림에서 유의한 치료효과가 있었다.

겨드랑이막증후군 환자에게 적용한 연부조직술기 치료는 상지 전 반적인 기능의 회복에 의미 있는 전후 차이를 나타내었다. Brurskens 등24은 겨드랑이막증후군 증상군과 대조군으로 나뉘어 수술 후 필 요한 운동 및 자세 교정, 림프부종을 예방하기 위한 특화된 운동, 수 술 육아조직을 위한 massage를 6개월간 적용하여 상지기능 회복에 유의한 차이를 보인 연구 결과를 보고하였다. 겨드랑이막증후군 환 자에 대한 적극적인 치료가 상지기능 회복에 유의한 효과를 가져올 수 있음을 시사한다. 본 연구에서의 치료 종료시점에서의 DASH 점 수는 10.89 점으로 Brurskens 등 24 의 연구에서 비슷한 점수대를 보인 수술 후 6개월에 보인 14.6점과는 기간적 차이가 많이 난다. 또한 Koehler 등 28 의 연구에서는 본 연구와 비슷한 기간인 4 주때의 DASH 를 통한 상지 기능 점수를 보게 되면 18.5점으로 다소 차이가 나타났 다. 선행연구 논문들에서는 비적극적인 치료방법을 택했으며 이는 자연 치유와 비슷한 치유기간을 보였지만 연부조직술기를 겨드랑이 막증후군 치료법으로 적용하게 되면 더 짧은 기간에 상지 기능을 회 복할수 있다고 사료된다.

통증에 있어서는 상지기능과 어깨관절가동범위의 회복과 함께 짧 은 기간에 통증 경감을 가져 왔다. 본 연구에서는 치료 종료시점이 평 균 4 주 정도에 VAS 점수 1.18 로 줄어들었고 최초 평가에 비해 유의한 감소를 보였다. Brurskens 등 24 의 연구에서 비슷한 점수대를 보인 3 개 월과는 기간적 차이가 많이 나며 Koehler 등 28 의 연구에서도 12 주때 의 VAS 점수가 1.5 였던 것과는 비슷한 결과를 보이지만 단기간에 좀 더 빠른 효과를 가져 올 수 있는 겨드랑이막증후군 치료법으로 연부 조직술기를 적용하기에 무리가 없어 보인다.

본 연구의 제한점으로는 case study로서 대조군의 설정 없이 실험 을 진행하였으며 결국 본 연구에서 사용한 치료법의 치료 적용 이후 치료 효과만을 본 것으로서 대조군을 통한 좀 더 통계적인 유의성을 확보해야 할 것이다. 또한 겨드랑이 수술은 전초림프점 조직검사와 겨드랑이 림프절 절제술로 나뉘는데 전초림프점 조직검사 수술한 사 람을 대상으로만 실시하여 겨드랑이 수술을 하는 유방암 환자에게 널리 적용하기 어려운 점이 있다. 다만 본 실험을 통해서 결론 내릴 수 
있듯이 연부조직술기가 전초림프점 조직검사 겨드랑이 수술을 한 유 방암 환자에게서 나타나는 겨드랑이막증후군을 짧은 시간 안에 증 상의 호전을 가져올 수 있는 치료법이며 치료 기간 동안 아무런 후유 증의 증감이 없는 안전한 치료라는 것을 확인하였다. 앞으로 대조군 과 함께 좀 더 다양한 환자군을 통한 연구로 발전하여 겨드랑이막증 후군 증상을 가진 겨드랑이 수술을 한 유방암 환자에게 보편 타당한 치료프로토콜 개발에 밑거름이 되었으면 한다.

\section{REFERENCES}

1. Namiranian N, Moradi-Lakeh M, Razavi-Ratki SK et al. Risk factors of breast cancer in the eastern mediterranean region: A systematic review and meta-analysis. Asian Pac J Cancer Prev. 2014;15(21):9535-41.

2. Saika K, Sobue T. [cancer statistics in the world]. Gan To Kagaku Ryoho. 2013;40(13):2475-80.

3. Ahmadian M, Samah AA. Application of health behavior theories to breast cancer screening among asian women. Asian Pac J Cancer Prev. 2013;14(7):4005-13.

4. statistics Nc. Ministry of health and welflare. Accessed June 13th, 2014. 2014.

5. Tasmuth T, von Smitten K, Kalso E. Pain and other symptoms during the first year after radical and conservative surgery for breast cancer. Br J Cancer. 1996;74(12):2024-31.

6. Carpenter JS, Andrykowski MA, Sloan P et al. Postmastectomy/postlumpectomy pain in breast cancer survivors. J Clin Epidemiol. 1998; 51(12):1285-92.

7. Rietman JS, Dijkstra PU, Hoekstra HJ et al. Late morbidity after treatment of breast cancer in relation to daily activities and quality of life: A systematic review. Eur J Surg Oncol. 2003;29(3):229-38.

8. Karki A, Simonen R, Malkia E et al. Impairments, activity limitations and participation restrictions 6 and 12 months after breast cancer operation. J Rehabil Med. 2005;37(3):180-8.

9. Shamley DR, Srinanaganathan R, Weatherall R et al. Changes in shoulder muscle size and activity following treatment for breast cancer. Breast Cancer Res Treat. 2007;106(1):19-27.

10. Torres Lacomba M, Mayoral Del Moral O, Coperias Zazo JL et al. Axillary web syndrome after axillary dissection in breast cancer: A prospective study. Breast Cancer Res Treat. 2009;117(3):625-30.

11. Springer BA, Levy E, McGarvey C et al. Pre-operative assessment enables early diagnosis and recovery of shoulder function in patients with breast cancer. Breast Cancer Res Treat. 2010;120(1):135-47.

12. Moskovitz AH, Anderson BO, Yeung RS et al. Axillary web syndrome after axillary dissection. Am J Surg. 2001;181(5):434-9.
13. Leidenius M, Leppanen E, Krogerus L et al. Motion restriction and axillary web syndrome after sentinel node biopsy and axillary clearance in breast cancer. Am J Surg. 2003;185(2):127-30.

14. Johnson S MI. Preparation of the breast cancer patient for radiotherapy planning. Physiotherapy. 2004;90:195-203.

15. Cheville AL, Tchou J. Barriers to rehabilitation following surgery for primary breast cancer. J Surg Oncol. 2007;95(5):409-18.

16. E. J. Physiotherpeutic treatment for axillary cord formation following breast cancer surgery. Pt_Zeitschrift für Physiotherapeuten. 2007;59: 868-78.

17. Fourie WJ, Robb KA. Physiotherapy management of axillary web syndrome following breast cancer treatment: Discussing the use of soft tissue techniques. Physiotherapy. 2009;95(4):314-20.

18. Lee JY, Lim JY, Oh JH et al. Cross-cultural adaptation and clinical evaluation of a korean version of the disabilities of arm, shoulder, and hand outcome questionnaire (k-dash). J Shoulder Elbow Surg. 2008;17(4): $570-4$.

19. Jester A, Harth A, Wind G et al. Disabilities of the arm, shoulder and hand (dash) questionnaire: Determining functional activity profiles in patients with upper extremity disorders. J Hand Surg Br. 2005;30(1):238.

20. Leonidou A, Woods DA, A preliminary study of manipulation under anaesthesia for secondary fronzen shoulder following breast cancer treatment. Ann R Coll Surg Engl. 2014;96(2):111-5.

21. Suami H, Taylor GI, Pan WR. The lymphatic territories of the upper limb: Anatomical study and clinical implications. Plast Reconstr Surg. 2007;119(6):1813-22.

22. Li CZ, Zhang P, Li RW et al. Axillary lymph node dissection versus sentinel lymph node biopsy alone for early breast cancer with sentinel node metastasis: A meta-analysis. European J Surg Oncol. 2015;41(8):958-66.

23. Bilimoria KY, Bentrem DJ, Hansen NM et al. Comparison of sentinel lymph node biopsy alone and completion axillary lymph node dissection for node-positive breast cancer. J Clin Oncol. 2009;27(18):2946-53.

24. Beurskens CH, van Uden CJ, Strobbe LJ et al. The efficacy of physiotherapy upon shoulder function following axillary dissection in breast cancer, a randomized controlled study. BMC Cancer. 2007;7:166.

25. MA. H. Preserving function in the inflamed and acutely injured hand. Clin Phys Ther. 1986;9:1-15.

26. Robson MC. Proliferative scarring. Surg Clin North Am. 2003;83(3): 557-69.

27. Henry G, Garner WL. Inflammatory mediators in wound healing. Surg Clin North Am. 2003;83(3):483-507.

28. Koehler LA, Blaes AH, Haddad TC et al. Movement, function, pain, and postoperative edema in axillary web syndrome. Phys Ther. 2015;95(10): 1345-53. 
Appendix 1. 연부조직술기(Soft tissue principles and treatment).

치료의 목적

근막 움직임(fascial glide)이 줄어든 부위에 조직의 움직임(tissue glide)을 회복한다.

연부조직 또는 근막의 운동성을 재정립하여 조직의 운동성 및 탄력성(mobility and flexibility)을 회복한다.

관절의 저가동성(hypomobility)을 회복하고 수동적 그리고 능동적 조직의 움직임 범위의 제한을 풀어준다.

조직의 움직임 평가

조직을 세로방향으로(longitudinally) 위쪽(superiorly) 또는 아래쪽으로(inferiorly) 움직여본다.

조직을 가로방향으로(transversely) 안쪽(medially) 또는 바깥쪽으로(laterally) 움직여본다.

조직을 시계(clockwise) 방향과 반시계(counterclockwise) 방향으로 움직여본다.

치료 기술

치료사의 손은 환자의 조직과 하나가 되어(unit) 피부 위에서 손이 움직일 수 있도록 한다.

손의 접촉부위는 손가락만을 사용하지 말고 손 전체를 접촉하여 실시한다.

손바닥 또는 손가락만을 사용할 경우에는 조직을 좀 더 가동화(mobilization)시켜야 할 경우에 적용한다.

피부(skin)와 얕은근막(superficial fascia), 깊은근막(deep fascia), 근육들 사이에 적용한다.

1 회 치료 : 움직임 평가에서 제한이 있는 범위에서 강도 설정에 따라 90 초간 유지한다.

치료 강도 설정

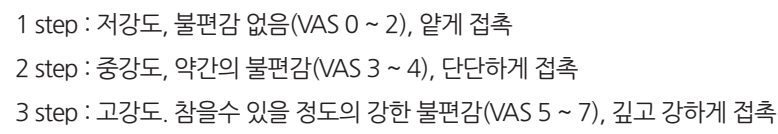

